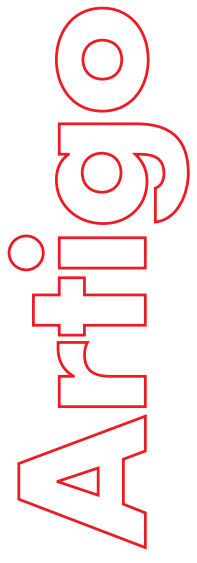

\title{
Geography of the Maracatu- Nação from Pernambuco and the Geographic Expansion of Groups in Brazil and Worldwide
}

\section{Cleison Leite Ferreira Rafael Sanzio Araújo dos Anjos}

p. $17-29$

\section{Magazine}

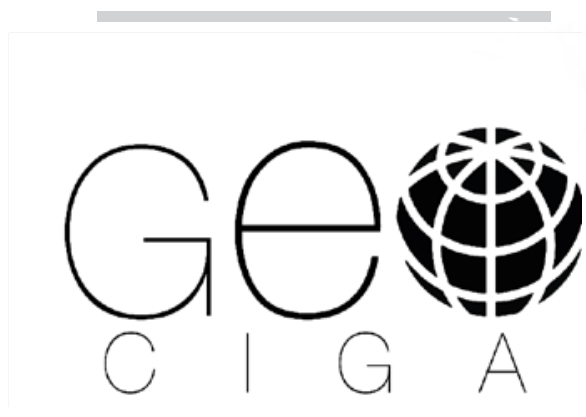

Eletronic Magazine: Tempo

- Técnica - Território, V.7,

N.2 (2015), 17:31 ISSN:

2177-4366

DOI: https://

doi.org/10.26512/

ciga.v7i2.19121
How to quote this article:

FERREIRA, C. Rafael Sanzio Araújo dos Anjos. GEOGRAPHY OF THE MARACATU-NAÇÃO FROM PERNAMBUCO AND THE GEOGRAPHIC EXPANSION OF GROUPS IN BRAZIL AND WORLDWIDE Revista Eletrônica: Tempo - Técnica - Território, v.7, n.2 (2016), p. 17:29 ISSN: 2177-4366. DOI: https://doi.org/10.26512/ciga.v7i2.19121

Available in: http://periodicos.unb.br/index.php/ciga

This work is licensed under a Creative Commons License 


\title{
GEOGRAPHY OF THE MARACATU-NAÇÃO FROM PERNAMBUCO AND THE GEOGRAPHIC EXPANSION OF GROUPS IN BRAZIL AND WORLDWIDE
}

\author{
Cleison Leite Ferreira \\ PhD - Geography \\ University of Brasilia \\ cleiferreira@yahoo.com.br \\ Rafael Sanzio Araújo dos Anjos \\ Full Professor - Department of Geography \\ University of Brasilia \\ quilombo.sanzio@gmail.com
}

\begin{abstract}
This paper aims to present the cartography of the Maracatu-Nação (an African-Brazilian expression) and the Maracatu groups in cadastral, national and international scales and to represent by mapping geographical expansion in Brazil and in other countries. We assume that the cartography of a cultural expression is expressed through the representation of the scale of social action in the production of geographical space and has its significance, since we can highlight its concreteness through maps. This work is multi-scale and has conceptual, technical and empirical basis. Its development happened with theoretical and conceptual discussion of culture as a producer of geographic space and how cartography is an important tool to represent this dynamic. For its development were used tools and mapping techniques, such as GPS and editing and mapping software, as ArcMap and Corel Draw. The field research allowed acquiring data in loco, photographic records, interviews, georeferencing, and taking headquarters measures and other Maracatus-Nação significant spaces for regarding the cadastral scale. The main results were cartographic products expressing the locations and the dynamics of the geographic expansion of Maracatu in national and international scales. It was found that the cartography is an important tool for cultural studies, especially with regard to the scales, and it stands for helping the analysis and interpretation of territorial identity. The Maracatus-Nação differ from the groups not only by their formal structures or ethnic and aesthetic elements. The geographical space defines and differentiates them, and can be represented, measured and analyzed by the use of cartography.
\end{abstract}

KEYWORDS: Maracatu-Nação, Cartography, Geographic Expansion

RESUMO: O objetivo desse trabalho é apresentar a cartografia do Maracatu-Nação de Pernambuco e a expansão dos grupos de maracatu nas escalas cadastral, regional, nacional e internacional. Pressupomos que a cartografia de uma manifestação cultural se expressa a partir da representação das escalas de ação na produção do espaço geográfico e tem sua importância na medida em que evidenciamos a sua concretude por meio de mapas. Nesse sentido, esse trabalho é multiescalar de base conceitual, técnica e empírica. Seu desenvolvimento ocorreu com a discussão teórico-conceitual sobre cultura enquanto produtora do espaço geográfico e de como a cartografia é um importante instrumento de representação dessa dinâmica. Para seu desenvolvimento foram utilizados instrumentos e técnicas de mapeamento, tais como GPS e softwares de edição e de elaboração cartográfica - ArcMap e Corel Draw. A pesquisa de campo possibilitou adquirir dados in loco, realizar registros fotográficos, entrevistas, georreferenciamento das coordenadas geográficas e 
tomadas de medidas de sedes e outros espaços significativos para os Maracatus-Nação referentes à escala cadastral. Os principais resultados apresentados foram produtos cartográficos que expressam a localização de Maracatus-Nação na RMR e a dinâmica da expansão geográfica de grupos de maracatu nas escalas nacional e internacional. Constatou-se que a cartografia é um importante instrumento para os estudos culturais, sobretudo no concernente às escalas, além de auxiliar na análise e na interpretação da identidade territorial. Os Maracatus-Nação se diferenciam dos grupos percussivos de maracatu não só por suas estruturas formais ou por seus referenciais étnicos e elementos estéticos. O espaço geográfico os define e os diferencia, e pode ser representado, mensurado e analisado pelo uso da cartografia.

PALAVRAS CHAVES: Maracatu-Nação, Cartografia, ExpansaGeographic Expansion

RÉSUMÉ : L`objectif de cette travail se présenter la cartographie de Maracatu- Nation de Pernambuco et les expansions des groupes de Maracatu dans aux escales, cadastral, nationale et international. On a supposé que la cartographie de une manifestation culturale que s'exprimer à partir des échelles de action dans la production de la zone géographique et avoir cette importance dans la mesure que nous attestions ses caractères concret par les cartes. Dans ce contexte, ce travail est multi escalait sur la base conceptuelle, technique et empirique. Ce développement se manifester avec la discussion théorique- conceptuel sur la culture tandis que producteur de la zone géographique et comment la cartographie c'est un appareil important de représentation de cette dynamique. Par ce développement a été utiliser appareils et techniques de cartographie, comme GPS et software de Edition et élaboration cartographique- ArcMap et Corel Draw. La recherche de terrain permettre acquérir l'information in loco, réalisée documentation photographique, entrevues, géo référencement de las coordonnés géographiques et prises de mesure de sièges et autres lieux significatifs par les Maracatus- Nation référents a échelles cadastrale. Les principaux résultats présentes a été produit cartographique qu'exprime la localisation de MaracatusNation dans le RMR et la dynamique d'expansion géographique de groupes de Maracatu dans échelles nationales et internationales. Á été constaté qui c'est un instrument important par les études culturales, surtout en ce qui concerne les échelles, plus qu'aider l'analyse d’interprétation de l'identité territoriale. Les Maracatus- Nation se différencient percussif de Maracatu non seulement par leur formel structures ou par ses référentiels ethniques et éléments esthétique. La place géographique est définie et différencié, pouvant être représenté, mesuré et examiné par l'usage de la cartographie.

MOTS CLÉS: Maracatu-Nation, Cartographie, Expansion géographique

\section{INTRODUCTION}

Brazil is a large country, with important records of the African presence in its territory started with the enforced diasporas occurred during the sixteenth and nineteenth centuries. The actions of African and african-Brazilian were significant and built in the cities and in the countryside a valuable diversity of lifestyles and spatial production, such as quilombos and the land of blacks, and construction of cultural expressions, currently recognized as heritage such as capoeira, frevo, samba and maracatu. These expressions crossed centuries and, despite suffering with numerous official repressions with the intention of being 
extinguished, they have been strengthened and are alive and active in everyday life in various cities such as Rio de Janeiro, Recife and Salvador, creating important resistance territories, where they do and reinvent their secular traditions.

Despite nearly five hundred years of African presence in Brazil, and considering that the main ethnic composition of the country is originally of the African continent, knowledge about African-Brazilian traditional territories and culture is sparse. These have been ignored and, if not, have been represented only as artifacts or elements of a folk condition, disregarding spatiality, historicity and activities of their doers, as if they were facts without a context.

We believe that between spatial structures, territory is configured as the best spatial dimension to the knowledge of the practices of population of African origin in Brazil, which for centuries was excluded and subjugated, but defined in space ways to aggregate around ethnic and cultural aspects, giving it the feeling of belonging, power and legitimacy from the heritage material and immaterial which affects spatially defining a territorial identity. Moreover, it is in the territory where "are recorded cultural and symbolic references of the population" (ANJOS, 2010, p. 7) and is where culminate, according to Santos (2006, p. 13) "all actions, all passions, all the powers, all the forces, and all the weaknesses". Is worth reminding that Milton Santos made it clear that territory, where life happens and where the social practices and the material and spiritual exchanges are carried out, should be taken as used territory, which is "ground and identity" (SANTOS, 2006, p. 14).

The territory is permeated with temporality and, through it, we can recognize the social processes of historical exclusion, conflict and resistance, especially with regard to the most significant ethnic references of the population as in the Brazilian case, African references. We consider in this respect that cartography is an important spatial representation instrument of human action that occurred in the past or that is happening in the present, providing information of what might happen in the future (ANJOS, 2010). With respect to traditional territories, the use of the cartography represents an unmatched meaning. This is because they are specific spatiality and temporality, that often suffer compression of global time and place, as the case of the Maracatu-Nação.

Maracatu-Nação, or Nation, is an African-Brazilian cultural expression originally from the Recife Metropolitan Region (RMR), in the state of Pernambuco, Brazil. Also known as "Maracatu de Baque Virado"1, has its origins dating back to the early nineteenth century, when still occurred in Recife a social and political practice of the African population known as election and coronation of Kings and Queens of Congo. It is characterized by a black royal procession that parades through the streets of the cities, especially during Carnival, and is made up of kings and queens who walk protected by a large umbrella, and princes and princesses, ladies of the court, ambassadors and spearmen. In addition to the royal characters there are still "damas do paço" (ladies of the Palace), that carry a doll named calunga (like a totem), and caboclos of forests, which are associated with the Brazilian Indians. Calungas and caboclos are endowed with a religious reference, because they represent symbols of African and Amerindian religions, of which the Maracatu-Nação is associated and maintains vital relationship. The characters of "Maracatu" properly dressed parade accompanied by a percussive orchestra and musicians who sing praises and plays the main musical instruments of a maracatu: alfaia, gonguê, ganza and tarol.

Since at least the year 1800 there are records of Maracatus-Nation in the RMR, where are currently found 27 Nations (as traditional Maracatus are called) living, acting

1 That means reverse sound of the drum.

Electronic Journal: Time - Technique - Territory, V.7, N.2 (2016), 17:29 ISSN: 2177-4366 
and producing not only a cultural event but defining traditional territoriality in communities and in the slums of central areas and the outskirts of the cities.

The Maracatu-Nação has obtained national and international recognition since the late twentieth century. At the headquarters of the Nations can be found people from different Brazilian states and other countries in search to know about it or learn how to play and/or to make musical instruments and perform a royal procession. This has led to the formation of Maracatu groups in Brazil and other countries in two ways: the percussive groups (concerned to reproduce the sound of Maracatu-Nação) and the stylized groups (groups that play music and reproduce the royal court).

Notably, the Nations and the maracatu groups are differentiated primarily by the identity and ethnic composition and religious dimension, since the former have religious obligations with the Candomblé (which worships the Orishas) and Jurema Sagrada (that enshrines the unseen beings of forests). However, with a closer analysis of the realities of both, you can identify that they also differ in the spatial dimension and by their scales of action.

In this sense, the objective of this paper is to present the cartography of the MaracatuNação and the geographic expansion process of groups in national and international scales in Brazil and in other countries. So, this is a multi-scale work, because it covers and represents cartographically the most intimate structures of Maracatu-Nation (the house, the offices, the reality in the neighborhood, etc.) - setting the cadastral and local scales - and the most extensive in the spatial records on national and international scales, in addition to the representation of the new spatial dynamics occurring on a global scale, with the formation of maracatu groups in Brazil and outside Brazil.

Thematic maps were elaborated with the help of photographic records as forms of representation, reading and interpretation of the territory. Both, mapping and photographs, are considered here important tools of work and research in relation to records of spatial dynamics and should not be seen as products with an end in themselves, but as instruments that reveal the historicity of human action, its impact at the present time and to future projections. Is worth noting that, as shown by Anjos (2011), maps as representation and graphic interpretation of the real world are effective tools for reading the territory and make it possible to reveal the "territoriality of social constructions and natural features of space and therefore show geographical facts and their conflicts" (ANJOS, 2011, p. 16 \& 17). Regarding the photography, Anjos says it is an important documentary resource of geographic knowledge due to "representations and interpretations of time, space and society, which are not crystallized or static” (ANJOS, 2011, p. 17). Still, according to Anjos the photographic record allows us to verify in society, particularly with regard to the social structure of a cultural matrix, "if it is rich or poor, fair or discriminatory" (Idem) and can be an important strategic tool for knowledge of what happens truly in the territory (ANJOS, 2011).

\section{METHODOLOGY}

The work was developed on two main lines of operationalization. The first was empirical, for primary data collection and recognition of studied and represented reality, and the other was technical, with the development of cartography and graphic representations of the studied object, as described below:

1st - Primary Data Collection - The information was collected directly with systematized field work that occurred between the months of May and August 2015 and 
February 2016, forming a set of primary data at the districts and headquarters of the Maracatus-Nação in the RMR and at the rehearsal spaces of maracatu groups in Brazil (in São Paulo, Florianopolis and Itajai), in Ireland (Dublin), in Germany (Berlin and Hamburg) and in the UK (London). To collect the data, we interviewed Masters and doers of Maracatus-Nação and members of maracatu groups at national and international scales, highlighting the territorial aspects of the organization of headquarters and the spatial practices of Nations and groups in their neighborhoods. Headquarters measurements were carried out and, with the use of GPS equipment (Global Positioning System), it was made the identification, cataloging and registration of geographical coordinates of the headquarters of Maracatus-Nação and maracatu groups. To mark the geographic position of the headquarters of the Maracatus-Nação, Google Earth satellite images were used with the help of the registration information provided by the Center of Afro-Brazilian Culture in Recife.

2nd - Cartographic products: A set of graphic and cartographic products was developed, such as:

- On the local scale: the RMR location map as territory itself of the Maracatu-Nação and map location of the seats, which represents its used territory.

- Cadastral scale: cartographic representation of the most intimate spatiality of the Maracatu-Nação which is its traditional territory.

- National and international scale: maps of location of the maracatu groups in Brazil and in the world and thematic maps that represent the processes of national and international geographic expansion of maracatu groups.

This research model was chosen to allow understand more accurately the territory of Maracatu-Nação as a social fact that can be categorized and measured as highlights Anjos (2011), besides allowing identifying and investigating its historical and contemporary incongruities that reach, especially the African-Brazilian population and its territoriality.

We have adopted in this work, the concept of territory associated with conceptions of culture as a production that is in progress, not as something finished or closed itself, which is intimately related to the space where it operates. Therefore, we conducted the cartography of Maracatu-Nação which is expressed in the location of this cultural expression in a larger space, which is the RMR, and in the strictest areas, such as cities, neighborhoods and communities/slums and its relation to the religions of African origin.

In this process, we identified that the Maracatu-Nação develops its practices in welldefined scales, when we consider its spatial and temporal dimensions of daily life and its used territory. Such scales of action are hereby recognized as "scales of reach" of the social practices (Corrêa, 2011, p. 41) where is possible to define the extent of the territory of the Maracatu-Nação and where it is located, takes place and produces geographic space. According to Roberto Corrêa (2011, p. 41-42)

The spatial scale is a fundamental feature of human action, related to practices that take place in more limited or broader spatial levels, but not dissociated from each other. (...).Scales or spatial areas are the signs and principles of human action inserted in its complex spatiality, which involves different purposes, means and ways.

The works of Rafael Sanzio dos Anjos bring us important information about the cartographic representation of human action and how this instrument is effective in the representation, reading and interpretation of the territory, especially in Brazil with its large size (Anjos, 2010). The territorialities composed of ethnic references are made in the scales of action, which are possible to be dimensioned and represented cartographically.

Electronic Journal: Time - Technique - Territory, V.7, N.2 (2016), 17:29 ISSN: 2177-4366 
The cartographic representation occurred in cadastral and local scales, because, besides allowing graphically express the fulfillment and spatiality of everyday social practices, these scales define the Maracatu-Nação as cultural event that takes place in the strictest contexts of large metropolitan region.

\section{CONCLUSIONS}

In the fieldworks we identified that there are Maracatus-Nação only in Pernambuco, in the municipalities of the RMR, and more specifically in Recife, Olinda, Jaboatão dos Guararapes and Igarassu, as shown in Map 1. This finding represents the local scale and refers to the territory itself. It, alone, does not allow us to understand the exact context of this cultural expression. This is because, according to Milton Santos (2006, 2013), this territory itself is more general and is form and set of natural systems and systems of superposed things of human action, which means territory itself. In that order, Milton Santos (2006, p. 14) continues: "the territory itself is not a category of analysis in historical disciplines such as geography”.

The identification of this metropolitan area as the territory itself helps us to recognize that this cultural expression has a broader context in which it operates and how it maintains an existential and belonging relationship with spatial entirety. Although it is not our analysis of reality, we recognize it is important as a way to locate spatially the studied object and serves as a counterpoint to spatiality which interests us, called used territory.

Milton Santos (2006, p. 14) defines used territory as "the ground plus the identity", that is, the sum of the territory itself more the social practices that take place in it and endow of full content of meaning, forming a feeling of belonging (SANTOS, 2013, p. 96). For Santos (2006, p. 14) "the territory is the basis of work, place of residence, the material and spiritual exchanges and the lifetime achievement" and this is the sense of territory that is category of geography analysis.

The identification of the used territory of the Maracatu-Nação was a methodological and conceptual exercise, since it was necessary to identify and to take another definition of Maracatu-Nação which occurred from also a vision of culture that goes beyond the classical notion. If we understand culture as a dynamic process, so we must also consider cultural practices as something ongoing. In this task, we sought to define the MaracatuNação from its geography and relationally with its realization space and spatial practices of its doers.

Maracatu-Nação "is not” (thing, static state), as something defined and over, as if it had come to a full level of its formation. Rather, it "is being" daily and constantly throughout the historical process and constantly communicability with the dynamic spatial context where it is inserted. Any attempt to describe it and set it should also be an exercise in contextualization spatiotemporal.

So with the Map 2, we approach the spatial reality where in fact the Maracatu-Nação happens - its used territory. For Zilá Mesquita (1995, p. 83), this is the "closest" space, which assumes intimacy. The used territory is defined from its most intimate spaces and can be represented in a cadastral scale. The use of photographic records was important in this process because it helped in the identification of local contexts of symbolic and practical spaces for Maracatu-Nação.

The relationship maintained with the religions of African origin is a central and significant issue with regard to Maracatu-Nação. The religion is an existential condition and synonymous of authenticity and is present in the discourses and practices of the 
Maracatu doers. It is expressed in the iconographic elements, the headquarters, the songs, the procession and the instruments, and intimately permeates its entire structure.

Map 1: Territory of the Maracatu-Nação - Pernambuco - Brazil

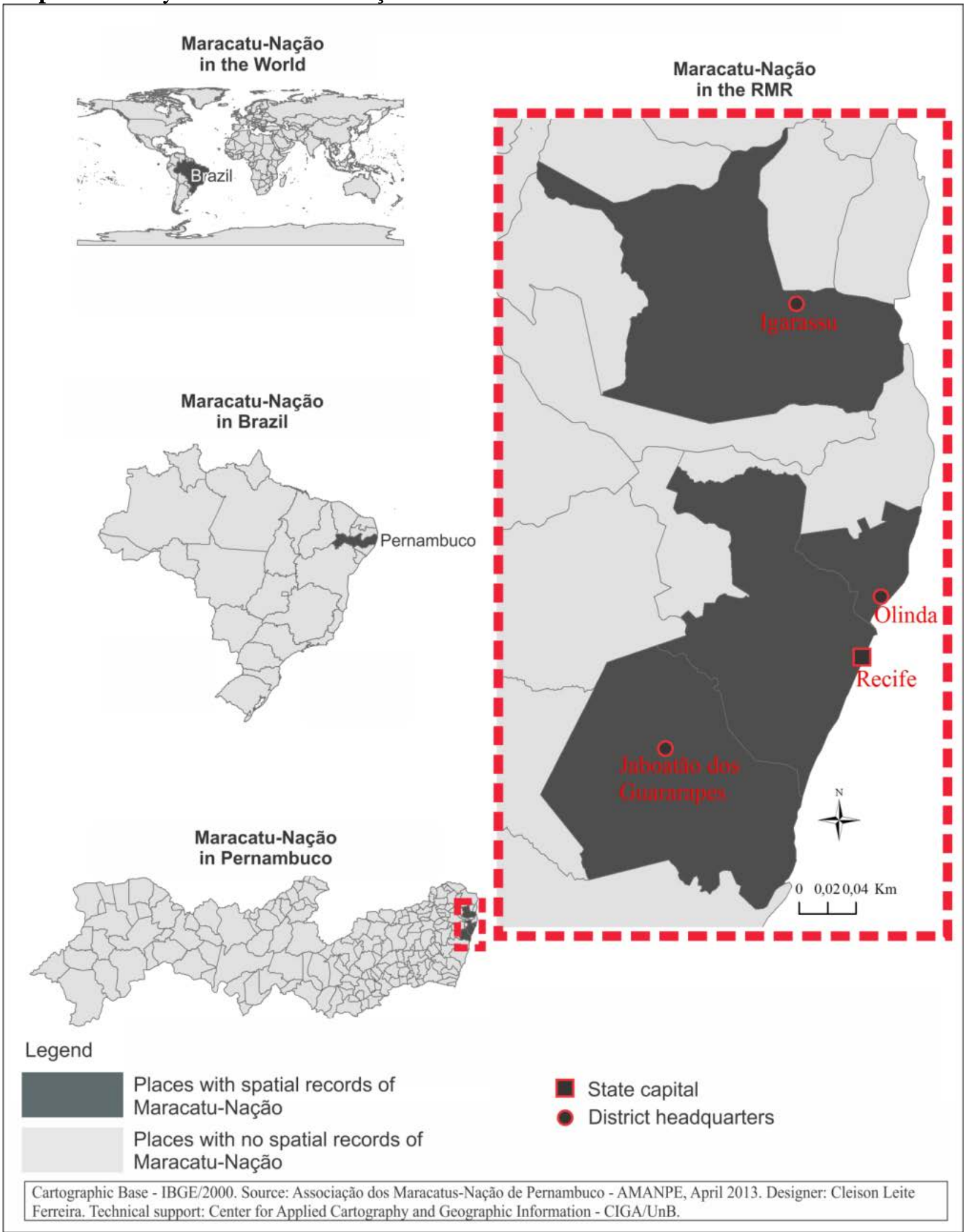

Electronic Journal: Time - Technique - Territory, V.7, N.2 (2016), 17:29 ISSN: 2177-4366 
Map 2: Spatial Records of Maracatus-Nação in Pernambuco - 2015

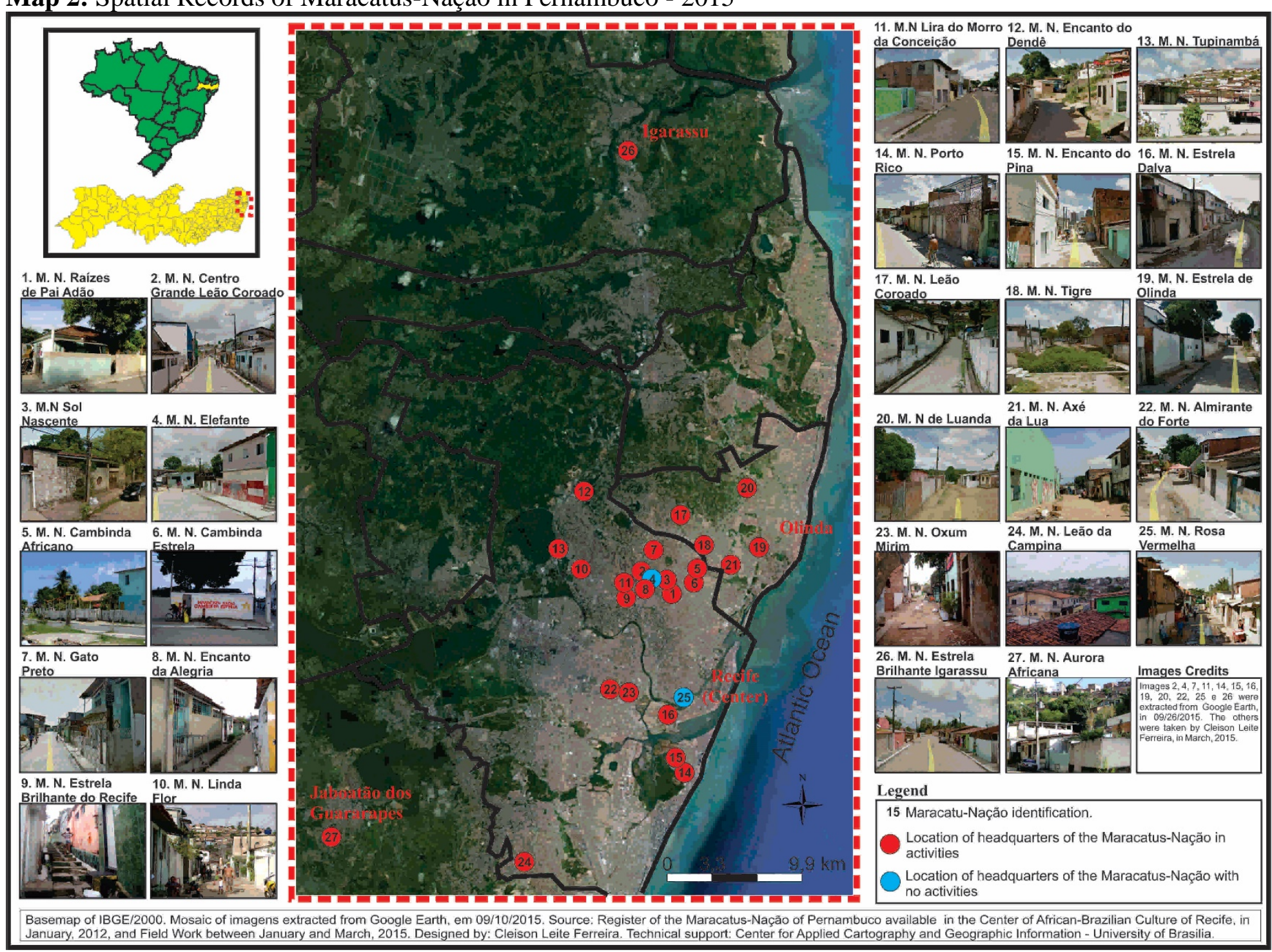

Electronic Journal: Time - Technique - Territory, V.7, N.2 (2016), 17:29 ISSN: 2177-4366 
Figure 1: The spatial structure of the headquarters of a Maracatu-Nação
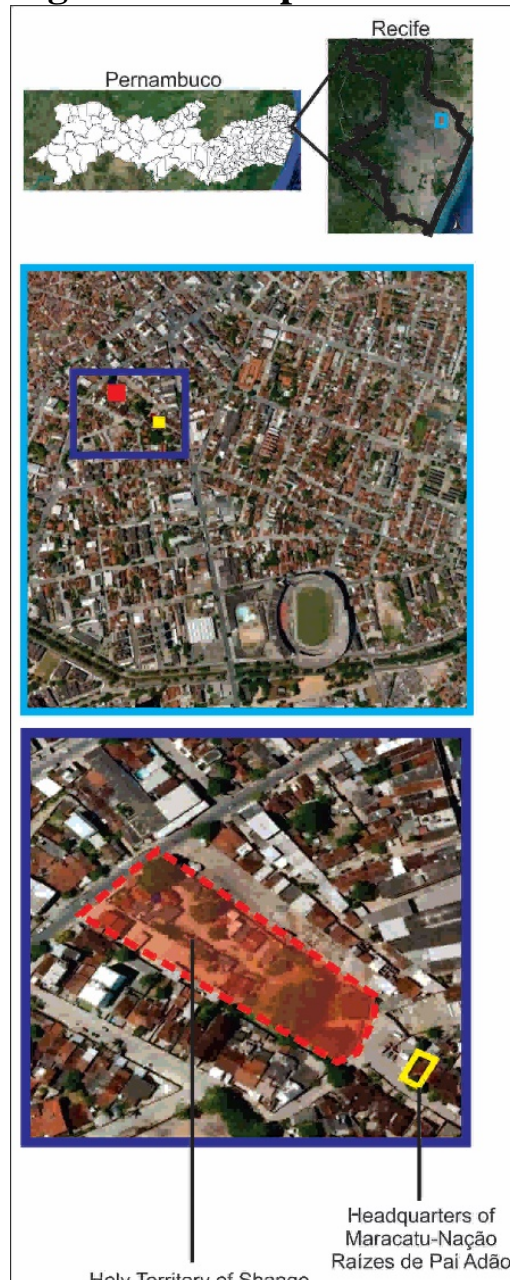

Holy Territory of Shango
Sítio (Temple) de Pai Adão

Sitio (Temple) de Pai Adãa
(llế Axé Obá Ogunté)
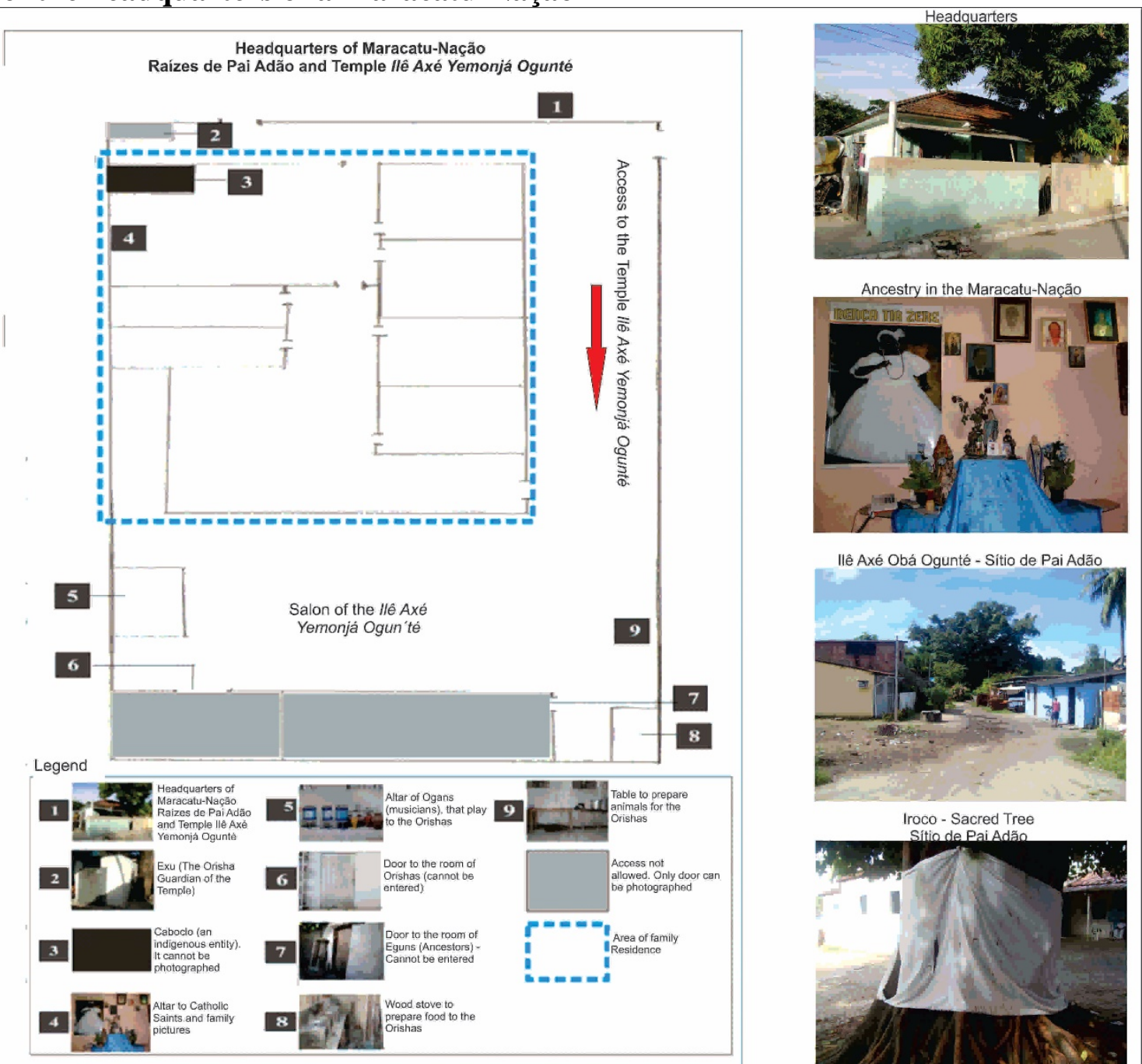

llê Axé Obá Ogunté - Sítio de Pai Adão

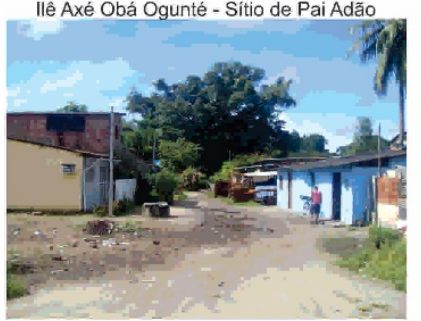

Iroco - Sacred Tree

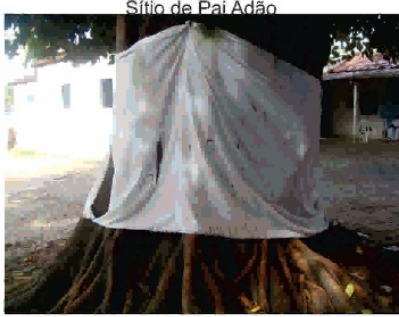

Basemap - Center for Applied Cartography and Geographic Information - CIGA/UnB. Images extracted from Google Earth, 11/21/2015. Photos/Design: Cleison Leite Ferreira.

Electronic Journal: Time - Technique - Territory, V.7, N.2 (2016), 17:29 ISSN: 2177-4366 
27 Geography of the Maracatu-Nação from Pernambuco and the Geographic Expansion of Groups in Brazil and Worldwide

This finding was possible by the cartographic representation of the headquarters. Enter its most intimate spaces allowed us to understand how, where and by whom this cultural expression is made. Thus cartographic representations of the headquarters were made. Figure 1 is one example among many others of how headquarters is organized, from its internal spaces to its relationship with the neighborhood, streets and religious spaces.

This representation shows the relationship between the Maracatu-Nação and the African-Brazilian and Amerindian religions. It is important to highlight how these religions carry of territoriality, considering the relationship with territory is vital to their achievement and is in the yard of their used territory, where are found their main symbolic elements and identity references. The ground, the nature, the religious temple, and the relationship with the everyday experience with place are key elements and define intrinsic territorialized spatial practices of religions, which the Maracatus-Nação maintain necessary and vital relationship.

The Maracatus and the headquarters are spaces where we find people that have shared their stories with each other: they are bricklayers, maids, teachers, students, collectors of recyclable materials, unemployed, street vendors and informal workers. These are people that make Maracatu in Recife and that with great difficulty and with meager financial resources available to them, take the Nations to the city center, magnifying the carnival and favoring the collection of amounts money for the government and the municipality, however, little money returns to them.

The Map 3 expresses the process of national and international geographic expansion of maracatu groups, identifying the direction of displacement and in which Brazilian states and in which countries there are spatial records.

The main spatial observation in this map is that most directions of displacements are towards Brazilian states, mainly of south and southeast regions, and to European countries, such as the United Kingdom, Ireland and Germany.

The percussive and stylized maracatu groups that have been forming since the end of the twentieth century in the national and international scales do not maintain the same relations with the space maintained by Maracatus-Nação in RMR. They are formed by some elements of the traditional Nations and do not share the same territorialized practices, nether the same identity and ethnic references. They consist chiefly of white youths, college students, who want more have fun. These groups are located and carry out their activities in middle-class neighborhoods.

Unlike Maracatu-Nações, the maracatu groups does not own headquarters, musical instruments are individual and are stored in the homes of participants. Also, they are not related to religions, which are the main defining elements of a Nation and the formation of a traditional territory.

While for the Maracatus-Nação practices are passed between generations, through exchanges of experience and orally or through interaction between children, young and elderly, making culture be renewed in symbolic ongoing and everyday life, to the maracatu groups this process takes place through courses, workshops, conducted by paid masters of traditional Pernambuco Nations. 
28 Geography of the Maracatu-Nação from Pernambuco and the Geographic Expansion of Groups in Brazil and Worldwide

Map 3: National and International Geographic Expansion of Maracatu Groups: Direction of Displacements and Spatial Records in Brazil and in the World

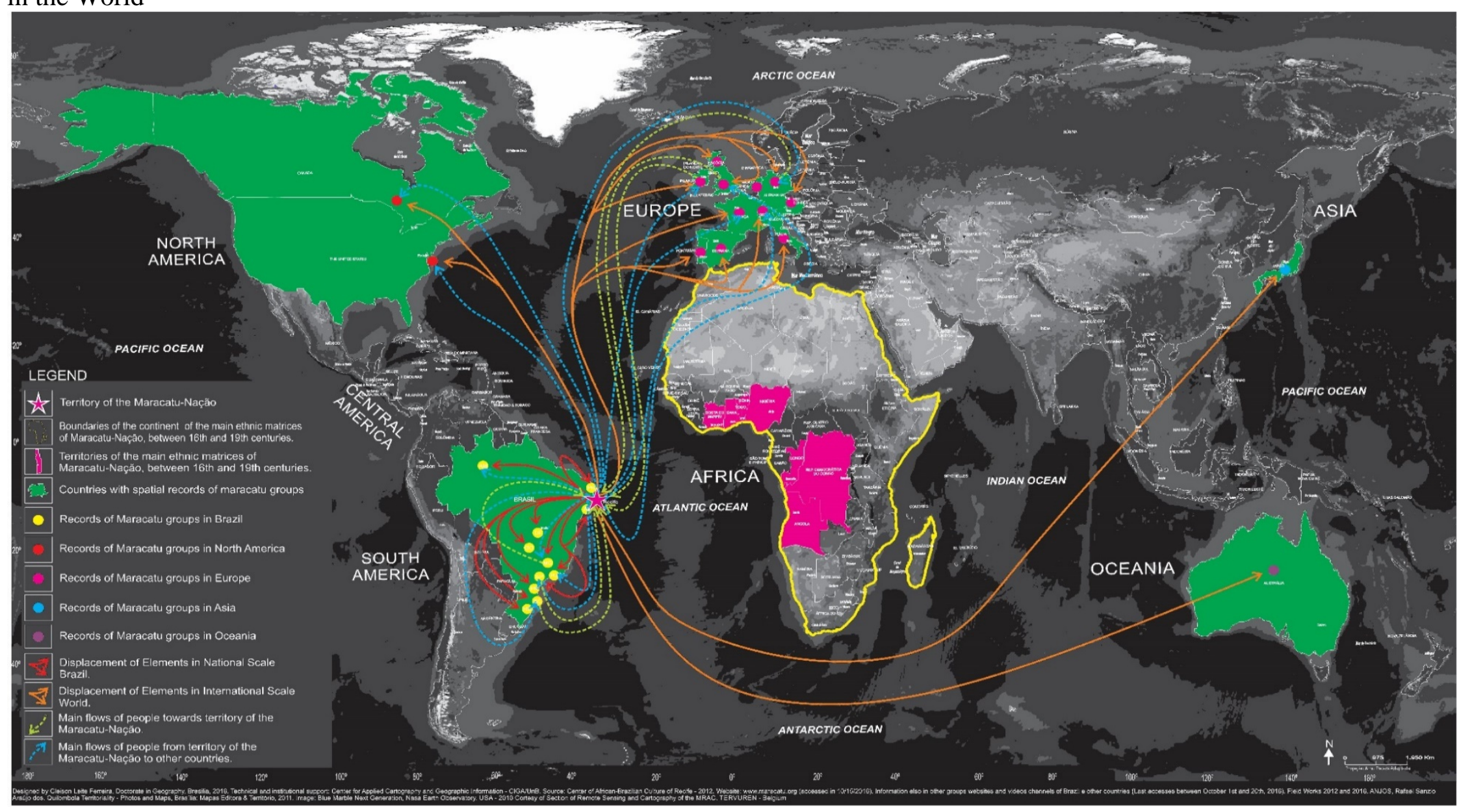

Electronic Journal: Time - Technique - Territory, V.7, N.2 (2016), 17:29 ISSN: 2177-4366 
29 Geography of the Maracatu-Nação from Pernambuco and the Geographic Expansion of Groups in Brazil and Worldwide

We assume that the cartography a cultural heritage is expressed through the representation of action scale in the production of geographical space and has its importance when evidenced its concreteness through maps. Specifically, we consider also that the cartography can be used as representation and interpretation of the two realities, because we believe that the differences between both pass the spatial dimension. Considering Maracatu-Nação has strong links with the communities of the center and the periphery of the cities and is performed by religious obligation, it has its importance to territorial identity and to its makers.

The identification and spatial location of the headquarters, associated with photographic records, enabled us to approach the contexts in which they are inserted. They are historical realities and shared with each other, with regard to processes of exclusion, abandonment or poor performance of the government towards the social actors, especially the black population, that struggle daily to maintain the survival and continuity of their cultural practices.

On the other hand, the map representing the national and international expansion shows local realities, which are, in most cases, megacities and global cities such as São Paulo, New York and London. This cartography with the help of photographic records reveals that maracatu groups formed in these realities are privileged contexts of access to better living conditions in urban areas. This finding was confirmed with the research fields, where also was possible with the interviews to identify the main ethnic origins that make up the groups take place of privilege, particularly in regard to racial prejudice and religious intolerance that live the doers of Maracatus-Nação of Pernambuco, in Brazil.

This cartography gives us the certainty that it is possible to represent the territorial dynamics involving Maracatus-Nação considering spatial aspects, temporality and the main identity and ethnic references of its composition, but also the status appropriations occur and how they are used in different scales.

\section{References}

ANJOS, R. S. A dos (2011). Territiorialidade Quilombola - Fotos e Mapas. Brasília: Mapas Editora e Consultoria.

ANJOS, R. S. A dos. (2010). A África brasileira: população e territorialidade. In: Textos Básicos do CIGA, Brasília: CIGA - CESPE.

CORRÊA, R.L. (2011). Sobre agentes sociais, escala e produção do espaço: um texto para discussão. In: CARLOS, Ana Fani Alessandri et. al. A produção do espaço urbano: agentes e processos, escalas e desafios, São Paulo: Contexto.

MESQUITA, Z. (1995) Do território à consciência territorial. In: MESQUITA, Zilá e BRANDÃO, Carlos Rodrigues. Territórios do cotidiano. Porto Alegre/Santa Cruz do Sul, UFRGS/UNISC.

SANTOS, M. (2006). O dinheiro e o território. In: Território, territórios - ensaios sobre o ordenamento territorial. Rio de Janeiro: DP\&A Editora.

SANTOS, Milton.(2013). Por uma outra globalização - do pensamento único à consciência universal. São Pauto: Record. 